\title{
Tako-tsubo syndrome after administration of intravenous adrenaline during atrioventricular block
}

\author{
Manuel Calvo-Taracido, Manuel Almendro-Delia, Juan C. Garcia-Rubira*
}

Unidad de Gestion de Cardiologia, Hospital Universitario Virgen Macarena, Sevilla, Spain;

*Corresponding Author: grubira@wanadoo.es

Received 20 October 2013; revised 22 November 2013; accepted 17 December 2013

Copyright (C) 2013 Manuel Calvo-Taracido et al. This is an open access article distributed under the Creative Commons Attribution License, which permits unrestricted use, distribution, and reproduction in any medium, provided the original work is properly cited. In accordance of the Creative Commons Attribution License all Copyrights (C) 2013 are reserved for SCIRP and the owner of the intellectual property Manuel Calvo-Taracido et al. All Copyright (C) 2013 are guarded by law and by SCIRP as a guardian.

\begin{abstract}
We describe the clinical case of a 70 -year-old woman with complete atrioventricular block that after administration of intravenous adrenaline, developed electrocardiographic changes suggestive of acute coronary syndrome, together with apical dyskinesia of the left ventricle. After ruling out the existence of coronary lesions, and after total recovery of the echocardiographic alterations in segmental contractility, she was diagnosed as Tako-tsubo syndrome induced by administration of adrenaline. This is the first report of this syndrome in the scenario of atrioventricular block treated with adrenaline infusion.
\end{abstract}

Keywords: Adrenaline; Asystole; Atrioventricular Block; Tako-Tsubo Syndrome

\section{CASE REPORT}

A 70-year-old woman suffered two episodes of syncope of a few seconds duration at home, with no prior chest pain. She had a previous history of hypertension, and no other significant pathologies. At the arrival of the emergency team, an electrocardiogram was performed, showing a complete atrioventricular block with episodes of asystole (Figure 1). Two milligrams of atropine and adrenaline infusion were administered immediately and the patient was then carried to the ambulance. A new electrocardiogram performed then showed intraventricular conduction disturbance and ST segment elevation in inferior and anterolateral leads together with the atrioventricular block (Figure 2). The patient suffered several episodes of syncope in the ambulance, with hemodynamic instability during all the transport time. On arrival at the emergency room, a temporary pacemaker was implanted, and the adrenaline infusion was retired. Decreased level of consciousness was the dominant symptom. Serial analysis revealed a modest rise of myocardial injury markers: Maximum CPK 92 U/L (normal < 195), Troponine-T $0.64 \mathrm{ng} / \mathrm{ml}$ (upper limit 0.05 ). Transthoracic echocardiography showed mild concentric hypertrophy (interventricular septum $13 \mathrm{~mm}$, posterior wall $14 \mathrm{~mm}$ ), and dyskinesia of the apical segments. Global systolic function was moderately depressed (left ventricular ejection fraction 0.45 ). Coronary angiography showed no angiographic lesions. On the third day she recovered sinus rhythm at 88 beats per minute with deep T-wave inversion in precordial leads (Figure 3). She underwent a permanent DDD pacemaker implantation, and was discharged fully asymptomatic. Control echocardiography 4 weeks later showed normal contractility.

\section{DISCUSSION}

Tako-tsubo syndrome was first described in Japan by Sato et al. [1]. It is characterized by a transitory ventricular dysfunction associated with elevation of myocardial damage enzymes in small amount in the absence of coronary lesions. Prognosis seems to be better with this syndrome than with the acute coronary syndrome [2]. ST-segment elevation is one of the characteristic presentations of this syndrome, and frequently involves anterior and inferior derivations [3], as it occurred in our case in the electrocardiogram of the early hours after admission. Other patients do not show this pattern, but only have $\mathrm{T}$-wave inversion. The $\mathrm{T}$-wave inversion presentation seems to be more frequent in Caucasian people [4].

There are several hypotheses about the pathophysiology of this syndrome; the most accepted is the catecholaminergic hypothesis. According to it, high levels of cathecolamines induced by stress result in myocardial 


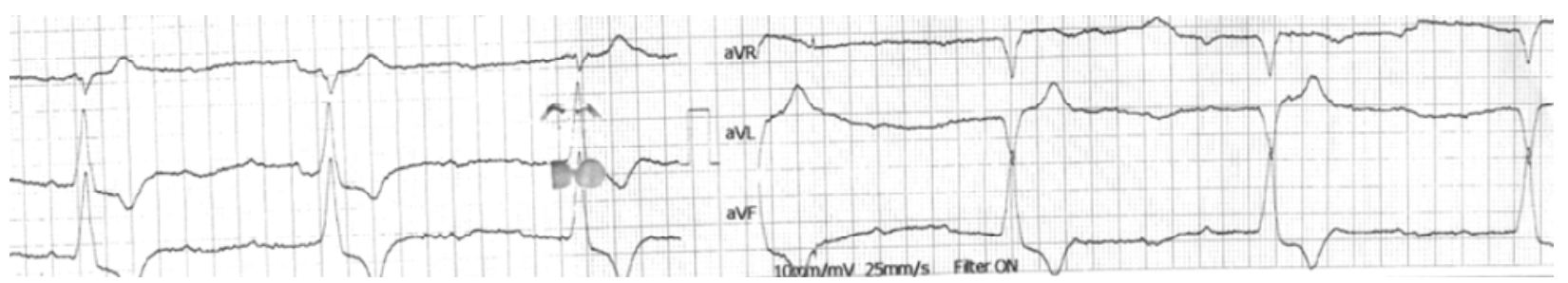

Figure 1. First electrocardiogram showed complete atrioventricular block.

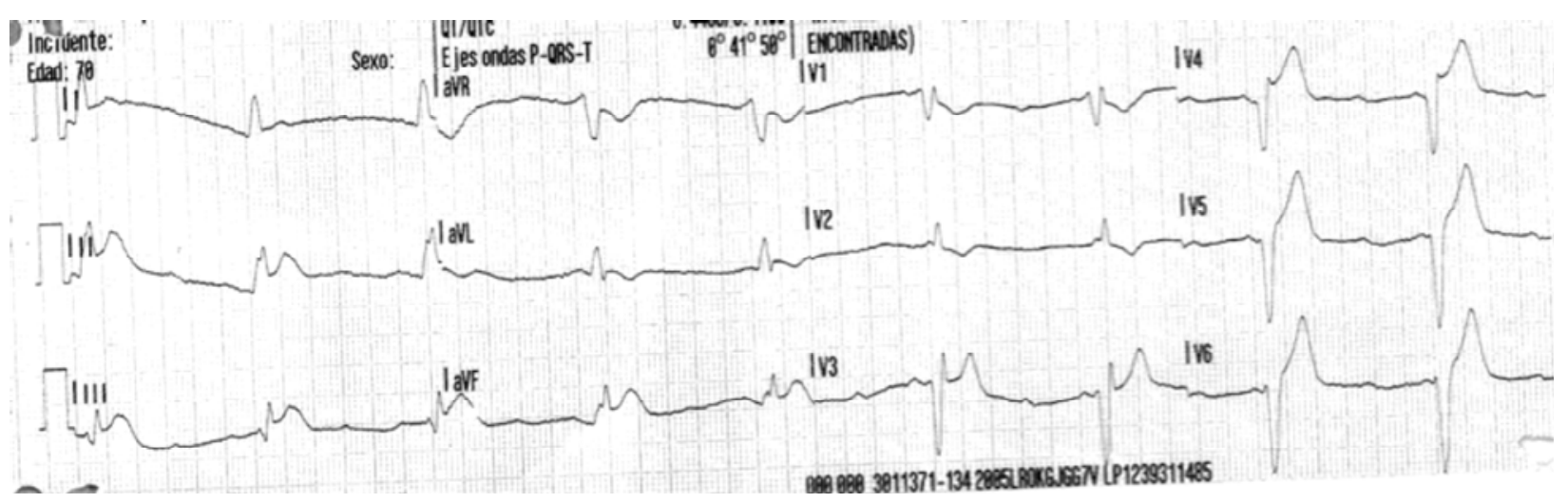

Figure 2. After adrenaline infusion, ST segment suggestive of myocardial infarction was observed (see leads DII, DIII and aVF).

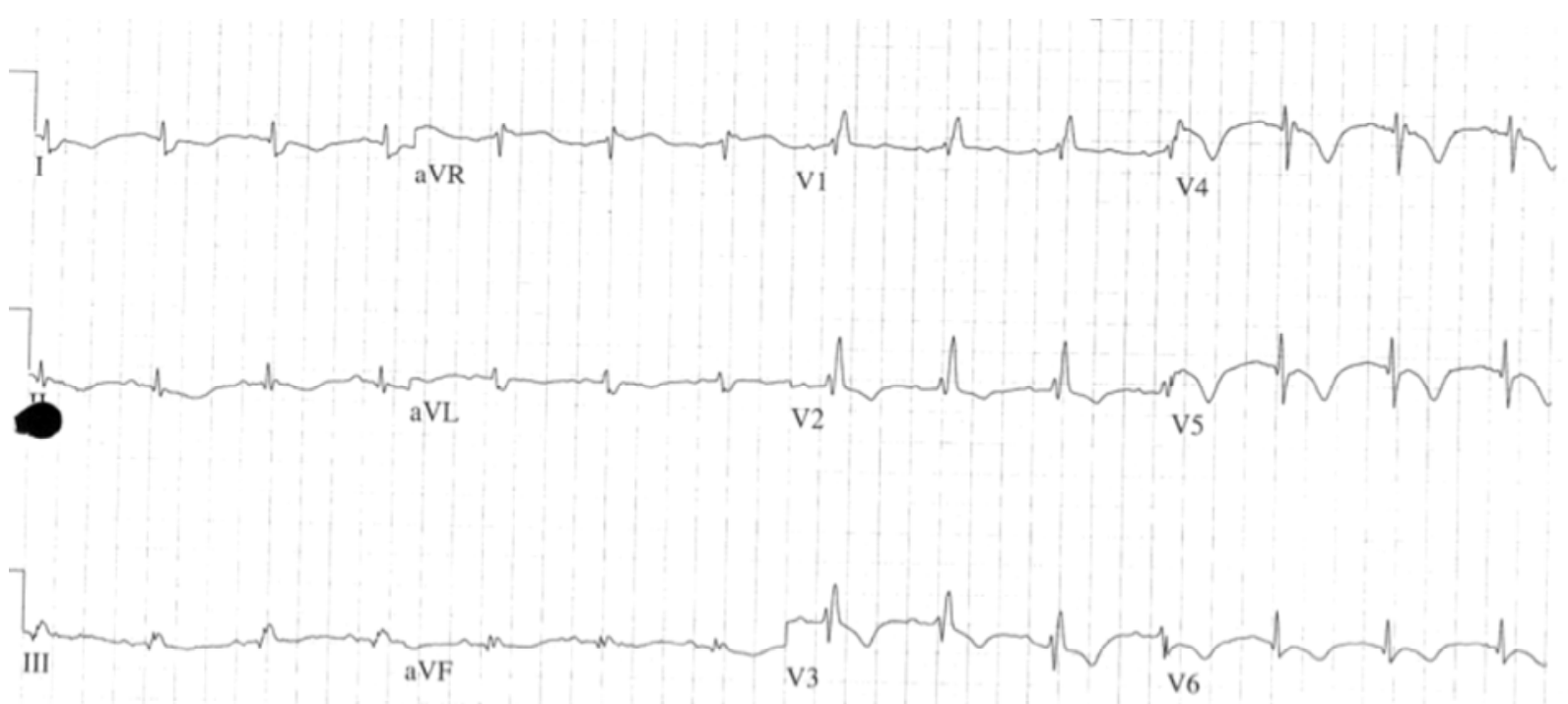

Figure 3. After recovering atrioventricular conduction, right bundle branch block and deep negative T waves appeared.

toxicity, either by excesive stimulation of adrenoreceptors and by microvascular dysfunction [5]. Plasma catecholamine levels have been found 3 times higher in patients with stress-related myocardial dysfunction compared with those in patients with Killip class III myocardial infarction [6]. Such levels overcome the physiological activation of beta adrenergic receptors in myocytes, and their coupling switches from Gs protein to Gi protein. As a consequence, the contractility is reduced, and the cell is protected from necrosis by this mechanism. The greater beta adrenergic receptor density in apical myo- cardium might explain the typical distribution of contractility alterations in Tako-Tsubo cardiomyopathy [7].

A few cases have been reported following administration of intravenous adrenaline under specific situations, as for treating anaphylactic reaction [8], but not in the scenario of atrioventricular block and asystole. Adrenaline, isoprenaline, and dopamine, are the recommended drugs in the treatment of symptomatic bradycardia not responsive to atropine, despite the well-known potential adverse effects, because of the need of restoring a stable heart rhythm [9]. Our case report calls for attention about 
the convenience of recommending an electrocardiogram whenever adrenaline treatment has been administered, and perform an echocardiogram and determinations of troponine or other necrosis markers if significant changes are found on them. Although a single case report does not have strength to generalize such a recommendation, clinicians involved in emergency departments should be aware of this possibility.

\section{REFERENCES}

[1] Sato, H., Tateishi, H. and Uchida, T. (1990) Takotsubotype cardiomiopathy due to multivessel spasm. In: Kodama, K., Haze, K. and Hon, M., Ed., Clinical Aspect of Myocardial Injury: From Ischemia to Heart Failure, Kagakuhyouronsya, Tokyo, 56-64.

[2] Núñez-Gil, I.J., Fernández-Ortiz, A., Pérez-Isla, L., Luaces, M., García-Rubira, J.C., Vivas, D., Gonzalez, J.J., Alonso, J., Zamorano, J.L. and Macaya, C. (2008) Clinical and prognostic comparison between left ventricular transient dyskinesia and a first non-ST-segment elevation acute coronary syndrome. Coronary Artery Disease, 19, 449-453. http://dx.doi.org/10.1097/MCA.0b013e32830eab74

[3] Zhan, Z.-Q., Wang, C.-Q., Sclarovsky, S., Niku, K.J., He, C.-R. and Shan, M. (2013) ST-segment deviation pattern of takotsubo cardiomyopathy similar to acute pericarditis: Diffuse ST-segment elevation. Journal of Electrocardiology, 46, 84-89. http://dx.doi.org/10.1016/j.jelectrocard.2012.11.013

[4] Donohue, D. and Movahed, M.R. (2005) Clinical charac- teristics, demographics and prognosis of transient left ventricular apical ballooning syndrome. Heart Failure Reviews, 10, 311-316. http://dx.doi.org/10.1007/s10741-005-8555-8

[5] Milinis, K. and Fisher, M. (2012) Takotsubo cardiomyopathy: Pathophysiology and treatment. Postgraduate Medical Journal, 88, 530-538.

http://dx.doi.org/10.1136/postgradmedj-2012-130761

[6] Wittstein, I.S., Thiemann, D.R., Lima, J.A., Baughman, K.L., Schulman, S.P., Gerstenblith, G., et al. (2005) Neurohumoral features of myocardial stunning due to sudden emotional stress. The New England Journal of Medicine, 352, 539-548. http://dx.doi.org/10.1056/NEJMoa043046

[7] Mori, H. (1993) Increased responsiveness of left ventricular apical myocardium to adrenergic stimuli. Cardiovascular Research, 27, 192-198. http://dx.doi.org/10.1093/cvr/27.2.192

[8] Winogradow, J., Geppert, G., Reinhard, W., Resch, M., Radke, P.W. and Hengstenberg, C. (2011) Tako-tsubo cardiomyopathy after administration of intravenous Adrenaline during an anaphylactic reaction. International Journal of Cardiology, 147, 309-311. http://dx.doi.org/10.1016/j.ijcard.2010.12.063

[9] Deakin, C.D., Nolan, J.P., Soar, J., Sunde, K., Koster, R.W., Smith, G.B. and Perkins, G.D. (2010) European resuscitation council guidelines for resuscitation 2010 section 4. Adult advanced life support. Resuscitation, 81, 1305-1352.

http://dx.doi.org/10.1016/j.resuscitation.2010.11.009 